\title{
Cellular Morphine Tolerance Produced by $\beta$ Arrestin-2-Dependent Impairment of $\mu$-0pioid Receptor Resensitization
}

\author{
Vu C. Dang, ${ }^{1}$ Billy Chieng, ${ }^{2}$ Yael Azriel, ${ }^{2}$ and MacDonald J. Christie ${ }^{1,2}$ \\ ${ }^{1}$ Pain Management Research Institute and Kolling Institute and ${ }^{2}$ Brain and Mind Research Institute, The University of Sydney, Sydney, New South Wales \\ 2006, Australia
}

\begin{abstract}
Chronic morphine treatment produces behavioral and cellular opioid tolerance that has been proposed to be caused by attenuated $\mu$-opioid receptor (MOR) recovery from desensitization (resensitization). The process of MOR resensitization is thought to require $\beta$ arrestin-2 ( $\beta$ arr-2)dependent trafficking of desensitized receptors to endosomal compartments, followed by recycling of resensitized receptors back to the plasma membrane. However, there is little direct evidence for this, particularly in native neurons. This study used whole-cell patch-clamp recording in locus ceruleus (LC) neurons from wild-type (w.t.) and $\beta$ arr- 2 knock-out (k.o.) mice to examine whether $\beta$ arr-2/dynamin-dependent trafficking is required for MOR resensitization in neurons from opioid-naive and morphine-treated mice. Surprisingly, recovery of MOR from acute desensitization in LC neurons does not require $\beta$ arr-2- or dynamin-dependent trafficking. To the contrary, MOR resensitization was accelerated by disruption of either $\beta$ arr- 2 or dynamin function. Chronic morphine treatment caused cellular MOR tolerance and concurrently impaired MOR resensitization in neurons from w.t. mice, as expected from previous studies, but neither occurred in neurons from $\beta$ arr- 2 k.o. mice. Moreover, the impairment of MOR resensitization caused by chronic morphine was reversed in w.t. neurons when G-protein-coupled receptor kinase-2 (GRK2) or dynamin function was disrupted. Together, these results establish that $\beta$ arr-2/dynamin-dependent receptor regulation is not required for MOR resensitization in LC neurons. Furthermore, chronic morphine treatment modifies GRK2- $\beta$ arr-2-dynamin-dependent MOR trafficking to impair receptor resensitization, thereby contributing to opioid tolerance in LC neurons by reducing the number of functional receptors on the surface membrane.
\end{abstract}

\section{Introduction}

Opioids are potent and effective analgesics, but their utility is greatly limited by the development of tolerance (Buntin-Mushock et al., 2005). Analgesic opioids mediate their effects by activating $\mu$-opioid receptor (MOR) (Kieffer and Gavériaux-Ruff, 2002). Sustained agonist activation of MOR initiates rapid regulatory events, including receptor desensitization and trafficking, that are thought contribute to the behavioral opioid tolerance that develops during prolonged opioid administration (von Zastrow, 2001). MOR regulation resembles that of the well characterized $\beta 2$ adrenoceptor. Briefly, G-protein-coupled receptor kinase-2 (GRK-2) phosphorylation of the agonist-bound $\beta 2$ adrenoceptor enhances its affinity for $\beta$ arrestin-2 ( $\beta$ arr-2) binding, triggering receptor endocytosis via clathrin-dynamin-dependent mechanisms (Gainetdinov et al., 2004). After endocytosis, receptors are resensitized and recy-

Received Nov. 16, 2010; revised Feb. 28, 2011; accepted March 2, 2011.

Author contributions:V.C.D., Y.A., and M.J.C. designed research; V.C.D., B.C., and Y.A. performed research;V.C.D., B.C., Y.A., and M.J.C. analyzed data; V.C.D. and M.J.C. wrote the paper.

This work was supported by National Health and Medical Research Council of Australia Program Grant 351446 and Fellowship 511914 (M.J.C.). We thank Drs. Lefkowitz and Caron for supply of the ßarrestin-2 knock-out mice.

Correspondence should be addressed to MacDonald J. Christie, Brain and Mind Research Institute, M02G, The University of Sydney, Sydney, NSW 2006, Australia. E-mail: mac.christie@sydney.edu.au.

V. C. Dang's present address: Department of Psychiatry, University of California, San Francisco, Genentech Hall, Room N-216P, 600 16th Street, San Francisco, CA 94158.

DOI:10.1523/JNEUROSCI.5999-10.2011

Copyright $\odot 2011$ the authors $\quad 0270-6474 / 11 / 317122-09 \$ 15.00 / 0$ cled (von Zastrow et al., 2003). For MOR, $\beta$ arr-2-dependent endocytosis and recycling are considered essential for receptor resensitization (Law et al., 2000; Koch et al., 2005), but there is no direct evidence for this. Indeed, blocking MOR endocytosis with concanavalin-A in neurons did not prevent MOR resensitization (Arttamangkul et al., 2006), suggesting that recycling may not be necessary for resensitization.

The failure of morphine to induce MOR endocytosis (Keith et al., 1996; Sternini et al., 1996) was proposed to cause morphine tolerance (Law et al., 2000; Koch et al., 2005) because desensitized MOR accumulates on the surface membrane in which it cannot resensitize. Such a mechanism is inconsistent with the in vivo finding that morphine tolerance is attenuated in $\beta$ arr- 2 knockout (k.o.) mice in which MOR endocytosis is presumably impaired (Bohn et al., 1999, 2000, 2002). Alternatively, attenuated opioid tolerance in $\beta$ arr- 2 k.o. mice may be caused by the loss of $\beta$ arr-2-mediated MOR desensitization in neurons. However, studies in single locus ceruleus (LC) (Dang et al., 2009) and dorsal root ganglion (DRG) (Walwyn et al., 2007) neurons have shown that MOR desensitization is unaffected by $\beta$ arr-2 deletion. Therefore, it remains unclear how $\beta$ arr-2-dependent MOR regulation contributes to cellular opioid tolerance in native neurons.

To determine the association between $\beta$ arr-2-dependent MOR regulation and cellular tolerance, we used whole-cell patch-clamp recordings to study MOR function in brain slices containing LC neurons from chronic morphine-treated wild- 
type (w.t.) and $\beta$ arr- 2 k.o. mice. The LC comprises a uniform population of MOR-expressing noradrenergic neurons in which homologous desensitization of MOR coupling to GIRK channels (GIRK) and cellular tolerance are well established (Connor et al., 2004). The results show that MOR resensitization does not require $\beta$ arr-2-dependent MOR trafficking or dynamin-dependent receptor endocytosis. MOR resensitization was actually more efficient when $\beta$ arr-2-dependent receptor trafficking was disrupted. Chronic morphine treatment produced cellular tolerance in LC neurons from w.t. but not $\beta$ arr-2 k.o. mice. Concurrently, MOR recovery from brief acute desensitization was impaired in neurons from morphine-treated w.t. but not $\beta$ arr-2 k.o. mice. This impairment of MOR resensitization in w.t. neurons was reversed when GRK-2 or dynamin function were disrupted. Together, these results show that $\beta$ arr-2-dependent trafficking is not required for MOR resensitization in LC neurons but does contribute to impaired receptor resensitization associated with cellular opioid tolerance.

\section{Materials and Methods}

Electrophysiology. Whole-cell recordings were made from 167 routinely genotyped, 5- to 16-week-old male $\beta$ arr-2 knock-out mice from Drs. Lefkowitz and Caron (Duke University, Durham, NC)) or their wildtype littermates (w.t. C57BL/6 background). LC slices were prepared as described previously for rats (Osborne and Williams, 1995). Briefly, mice were anesthetized with isoflurane ( $4 \%$ in air) and decapitated, and horizontal vibratome (Leica VT1000) sections $(200-220 \mu \mathrm{m})$ were prepared at $4^{\circ} \mathrm{C}$ and then incubated in extracellular solution (ACSF, $60 \mathrm{~min}, 37^{\circ} \mathrm{C}$ ). ACSF contained the following (in $\mathrm{mm}$ ): $126 \mathrm{NaCl}, 2.5 \mathrm{KCl}, 2.4 \mathrm{CaCl}_{2}, 1.2$ $\mathrm{MgCl}_{2}, 1.2 \mathrm{NaH}_{2} \mathrm{PO}_{4}, 21.4 \mathrm{NaHCO}_{3}$, and 11.1 glucose $\left(95 \% \mathrm{O}_{2} / 5 \% \mathrm{CO}_{2}\right.$ at $37^{\circ} \mathrm{C}$ ). Pipette $(2-4 \mathrm{M} \Omega$ ) solution contained the following (in $\mathrm{mM}$ ): $115 \mathrm{~K}-\mathrm{MES}, 20 \mathrm{KCl}, 1.5 \mathrm{MgCl}_{2}, 10 \mathrm{BAPTA}, 5 \mathrm{HEPES}, 4 \mathrm{Mg}$-ATP, and 0.4 Na-GTP, pH 7.3-7.4. Voltage-clamp recordings of visualized LC neurons (infrared Nomarski optics; holding potential, -55 to $-60 \mathrm{mV}$ ) were acquired using Axograph X (Axograph Scientific) and filtered at $10-100 \mathrm{~Hz}$. Bestatin $(10 \mu \mathrm{M})$ and thiorphan $(1 \mu \mathrm{M})$ were included in all experiments using met $^{5}$-enkephalin (ME). All experiments were approved by the Royal North Shore Hospital/University of Technology Sydney Ethics Committee, which complies with National Health and Medical Research Council of Australia guidelines.

For recording in LC neurons, inhibitory peptides or microcystin were backfilled into the recording electrodes. Soon after achieving whole-cell access ( $\leq 5 \mathrm{~min}$ ), GIRK activation in LC neurons by a low concentration of naloxone (NA) $(3 \mu \mathrm{M})$ or ME (300 nM) was assessed to determine the control response. Neurons were then dialyzed with inhibitory peptide or microcystin for up to $60 \mathrm{~min}$, during which NA ( $3 \mu \mathrm{M})$ or ME (300 nм) activation of GIRK was assessed periodically. No changes in NA $(3 \mu \mathrm{M})$ or ME (300 nM) activation of GIRK currents were detected by the loading of inhibitory peptides $(100 \mu \mathrm{M})$ or microcystin $(25 \mathrm{nM})$ (data not shown).

MOR internalization. Mouse AtT20 neuroblastoma cells stably transfected with $\mathrm{N}$-terminal Flag-tagged ì-opioid receptors (FLAG-MOR) as described previously (Borgland et al., 2003) were grown to $90 \%$ confluence in DMEM containing fetal bovine serum (10\%), penicillin/streptomycin $(50 \mathrm{U} / 5 \mu \mathrm{g} / \mathrm{ml})$ and $\mathrm{G} 418(5 \mu \mathrm{g} / \mathrm{ml})$, passaged, and seeded onto poly-L-lysine $(100 \mu \mathrm{g} / \mathrm{ml})$-coated glass coverslips $(\sim 50 \%$ density $)$ in 35 $\mathrm{mm}$ dishes. The day after passage, coverslips were placed in extracellular HEPES-buffered saline (HBS) solution [in mM: $150 \mathrm{NaCl}, 2.5 \mathrm{KCl}, 1.8$ $\mathrm{CaCl}_{2}, 1 \mathrm{MgCl}_{2}, 10$ HEPES, 10 glucose, $\mathrm{pH} 7.3$ (330 $\left.\left.\pm 5 \mathrm{mOsm}\right)\right]$ at room temperature and allowed to equilibrate for $30 \mathrm{~min}$ before the commencement of the experiment. Patch-clamp recording pipettes were filled with internal solution containing $5 \mathrm{~mm} \mathrm{NaCl}, 130 \mathrm{~mm} \mathrm{KCl}, 10 \mathrm{~mm}$ EGTA, 20 mм HEPES, 2 mм $\mathrm{CaCl}_{2}$, 5 mм MgATP, $0.2 \mathrm{~mm} \mathrm{NaGTP,} 1.5 \mathrm{mg} / \mathrm{ml}$ biocytin alone (Sigma) or biocytin plus either a myristilated dynamin inhibitory peptide (DYNi) (100 $\mu \mathrm{M}$; Tocris Bioscience) or a GRK2 inhibitory peptide (GRK2i) (100 $\mu \mathrm{M}, \mathrm{pH} 7.3,285 \pm 5 \mathrm{mOsm})$. Electrodes were made with fire-polished borosilicate glass (A-M Systems) and had an average resistance of $\sim 2.5 \mathrm{M} \Omega$. Individual cells were loaded with inhibitor/biocytin using a whole-cell configuration of the patch-clamp tech- nique and by diffusion from the pipette shaft. Cells were voltage clamped at $-60 \mathrm{mV}$ and filled for 1, 5, or $10 \mathrm{~min}$. Intracellular exposure to GRK2 or dynamin inhibitory peptides for $5 \mathrm{~min}$ or less did not produce reliable inhibition of endocytosis (data not shown). Patch electrodes were then carefully removed from the cell, and the cell was allowed to recover for 10 min. Cells were then transferred into HBS containing $\mathrm{ME}(30 \mu \mathrm{M})$, bestatin $(10 \mu \mathrm{M})$, and thiorphan $(1 \mu \mathrm{M})$ and incubated at $37^{\circ} \mathrm{C}$ for $30 \mathrm{~min}$ to induce internalization of FLAG-MOR. Incubations were stopped in icecold PBS $(0.1 \mathrm{M}, \mathrm{pH} 7.2)$, fixed in $4 \%$ paraformaldehyde for $20 \mathrm{~min}$, and then rinsed thoroughly with PBS at $4^{\circ} \mathrm{C}$. Cells were permeabilized $\sim 24 \mathrm{~h}$ after fixation with ice-cold, absolute methanol for $5 \mathrm{~min}$ and then rinsed with PBS. They were then incubated with $10 \%$ normal goat serum for $1 \mathrm{~h}$ at room temperature and then for $2 \mathrm{~h}$ at room temperature with an anti-FLAG polyclonal antibody $(2 \mu \mathrm{g} / \mathrm{ml})$ raised in rabbit (Sigma). After three $10 \mathrm{~min}$ rinses with PBS, cells were incubated for $90 \mathrm{~min}$ with avidinconjugated Alexa Fluor-647 (1:500; Invitrogen) and an anti-rabbit Alexa Fluor-488-conjugated secondary antibody (1:200; Invitrogen) diluted with $2 \%$ normal goat serum in PBS. Coverslips were washed three times with PBS and then mounted onto slides with Fluoromount (Sigma) mounting medium. Images were acquired with an Olympus FV300 confocal microscope using a $60 \times$ oil objective and a $1.5 \times$ digital zoom, and extent of internalization was scored by an observer blind to peptide exposure during patch-clamp recording.

Chronic morphine treatment. Mice were lightly anesthetized with isoflurane as described previously (Bagley et al., 2005a). Three subcutaneous injections of a sustained release preparation of morphine [free base $300 \mathrm{mg} / \mathrm{kg}$ suspended in $0.1 \mathrm{ml}$ of Arlacel A (mannide monooleate), $0.4 \mathrm{ml}$ of light liquid paraffin, and $0.5 \mathrm{ml}$ of $0.9 \% \mathrm{w} / \mathrm{v} \mathrm{NaCl}$ ] on alternate days over a $5 \mathrm{~d}$ period. Vehicle mice were injected with suspension lacking morphine.

Statistics and curve fitting. Data were analyzed using PRISM (GraphPad Software). Values are given as mean \pm SEM. Statistical comparisons were made with $t$ tests (for two groups) or two-way ANOVA with Bonferroni's post hoc tests and considered significant if $p<0.05$.

Reagents. Reagents were from the following: ME, thiorphan, and bestatin were from Sigma and naloxone, morphine base, and GSK were from RBI. The GRK2i sequence W643-S670 (Ac-WKKELRDAVREAQQLVQRVPKMKNKPRS-NH2, >95\%) was custom synthesized by AUSPEP and dynamin inhibitory peptide by Tocris Bioscience.

\section{Results \\ $\beta$ Arrestin-2 deletion accelerates the rate of MOR resensitization}

Desensitization was defined here as the loss of MOR function that develops rapidly (several minutes) during sustained application of high concentrations of agonists (Connor et al., 2004). Activation of MOR with a supramaximal concentration of the endogenous opioid $\mathrm{ME}$ ( $30 \mu \mathrm{M}, \geq 10 \mathrm{~min}$ ) has been widely reported to produce maximal desensitization and robust MOR endocytosis in LC neurons (Osborne and Williams, 1995; Bailey et al., 2004; Dang and Williams, 2005; Arttamangkul et al., 2006; Dang et al., 2009). Desensitization of MOR-activated GIRK currents in LC neurons provides a rapid, reliable assay of G-protein activation that does not involve loss of channel function because agonists at other GPCRs are still able to fully activate GIRK currents when MOR is desensitized in these cells (Connor et al., 2004). We previously reported that the rate and extent of agonist-induced acute desensitization of GIRK currents are nearly identical in LC neurons from w.t and $\beta$ arr- 2 k.o. mice and that GIRK activation can still be achieved by $\alpha 2$ adrenoceptor agonist, confirming that desensitization of MOR-activated GIRK is mostly homologous (Dang et al., 2009). Figure 1 confirms that acute desensitization of MOR-activated GIRK currents was unaffected by $\beta$ arr- 2 deletion (Dang et al., 2009). As reported previously in detail (Dang et al., 2009), the peak GIRK current activated by ME (30 $\mu \mathrm{M})$ was slightly smaller in $\beta$ arr- 2 k.o. than w.t. mice ( $77 \pm 9 \mathrm{pA}, n=13$ vs $94 \pm 7 \mathrm{pA}, n=15$, respectively; $p>0.157)$, as was the response to 

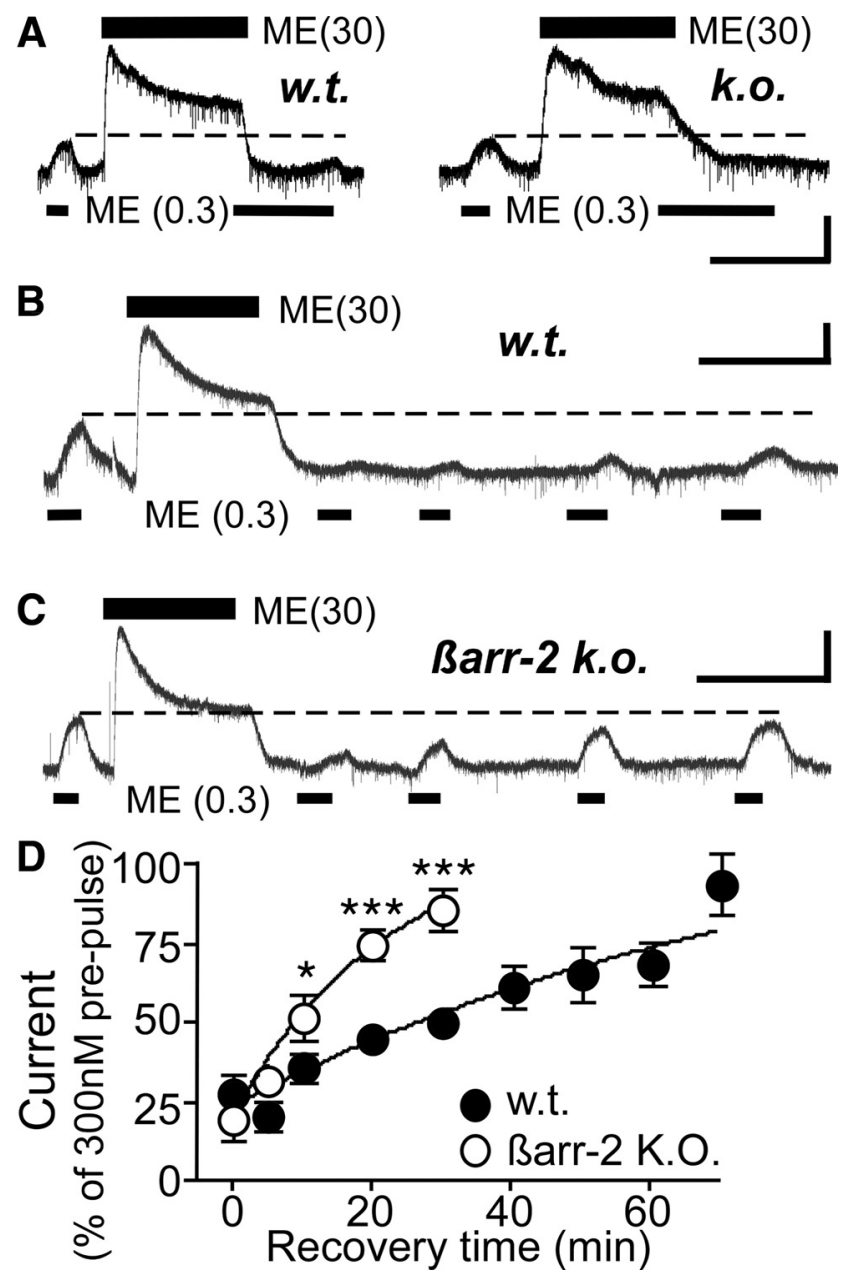

Figure 1. MOR recovery from 10 min desensitization is faster in $\mathrm{L} C$ neurons from $\beta$ arr-2k.o. mice. A, GIRK current records of $\mathrm{LC}$ neurons from w.t. (left) and $\beta$ arr-2 k.o. (right) mice showing rapid desensitization during ME superfusion ( $30 \mu$; shown by bar above trace) is not impaired by $\beta$ arr-2 deletion for both decline in the maximal GIRK current or when probed with a submaximal concentration (300 nм; bar below traces). B, MOR resensitization (recovery of ME $300 \mathrm{~nm}$ response; bars below trace) shown at various time points in w.t. LC. C, Current record of $L C$ neuron from $\beta$ arr-2 k.o. mouse showing that $M E-$-induced $M O R$ desensitization was the same as $\mathrm{LC}$ neuron from w.t. mice but recovery was more rapid. $\boldsymbol{D}$, Summary for MOR resensitization for neurons from w.t. $(n=7,7,14,16,18$, $10,7,6$, and 3 for $0-70$ min time points, respectively) and $\beta$ arr- 2 k.o. $(n=4,4,15,16$, and 10 for $0-30$ min time points, respectively) mice [two-factor ANOVA, $p<0.0001$ ( post hoc Bonferroni's tests $\left.\left.{ }^{*} p<0.05,{ }^{* * *} p<0.001\right)\right]$. Calibration: $25 \mathrm{pA}, 10 \mathrm{~min}$.

a submaximal concentration of $\mathrm{ME}(300 \mathrm{nM} ; 21 \pm 3 \mathrm{pA}, n=24 \mathrm{vs}$ $26 \pm 3 \mathrm{pA}, n=16$, respectively; $p>0.22$ ) (Fig. $1 A-C$ ). The potency of $\mathrm{ME}$ was also similar in $\beta$ arr- 2 k.o. and w.t. LC neurons $\left[\mathrm{pEC}_{50}\right.$ from nonlinear logistic fitting: 5.74 vs $5.88(-\log \mathrm{M})$, respectively]. This suggests little or no change in efficacy of MOR coupling to GIRK in LC neurons from $\beta$ arr-2 k.o. as reported previously (Dang et al., 2009). Desensitization of the peak response after $10 \mathrm{~min}$ exposure to $\mathrm{ME}(30 \mu \mathrm{M})$ did not differ between $\beta$ arr- 2 k.o. and w.t. LC neurons ( $51 \pm 4 \%$ of the initial peak, $n=13$ vs $54 \pm 3 \%, n=15$, respectively) (Fig. $1 A$ ). MOR desensitization determined using a submaximal probe concentration of ME (300 nM) applied immediately after washout of the supramaximal concentration is identical $[29 \pm 6 \%(n=4)$ vs $28 \pm 6 \%(n=7)$ of the prepulse response, respectively] (Fig. $1 A)$. These findings confirm that a submaximal probe concentration of ME (300 nM) provides a sensitive measure of MOR function that is comparable across genotypes (Connor et al., 2004).
Experiments were then conducted to determine the effect of Barr-2 deletion on MOR recovery from acute desensitization. Receptor resensitization was assessed by comparing MOR activation of GIRK by ME (300 nM) before and at various times after desensitization. Consistent with previous reports (Osborne and Williams, 1995; Dang and Williams, 2004), MOR activation of GIRK exhibited slow but progressive recovery after the washout of $\mathrm{ME}(30 \mu \mathrm{M} ; 10 \mathrm{~min})$. In neurons from w.t. mice, MOR resensitization approached full recovery after $70 \mathrm{~min}$ (Fig. $1 B, D$ ). In contrast, MOR resensitized more rapidly in neurons from $\beta$ arr-2 k.o. mice (Fig. 1C,D) ( $p<0.0001$, two-factor ANOVA). MOR activation of GIRK fully recovered after 20-30 min in neurons from $\beta$ arr- 2 k.o., whereas at the same time points, neurons from w.t. mice exhibited only $45 \pm 3 \%(n=16)$ and $51 \pm 3 \%(n=18)$ recovery, respectively (Fig. $1 D$ ).

\section{Disruption of $\boldsymbol{\beta}$ arrestin-2-dependent receptor trafficking} accelerates MOR resensitization

The finding that MOR resensitization is more efficient in LC neurons from $\beta$ arr- 2 k.o. mice suggests that MOR resensitization does not require $\beta$ arr-2-dependent receptor trafficking and, presumably, receptor endocytosis. To corroborate this, manipulations were applied to prevent $\beta$ arr-2-dependent MOR endocytosis in LC neurons from w.t. mice. MOR endocytosis was disrupted either upstream (GRK2 inhibition) or downstream (dynamin inhibition) of $\beta$ arr-2 association with the MOR (Gainetdinov et al., 2004). First, neurons from w.t. mice were loaded intracellularly with a GRK2i peptide via the recording electrode $(100 \mu \mathrm{M})$ to disrupt GRK2 activation by G $\beta \gamma$ subunits (Koch et al., 1993; Li and Wang, 2001; Dang et al., 2009).

Confirmation that GRK2i peptide disrupted $\beta$ arr-2-dependent endocytosis was performed in cultured cells because quantification of endocytosis of native MOR in LC is not readily achieved using confocal microscopy (Scavone and Van Bockstaele, 2009), particularly after preparation of brain slices and whole-cell recording procedures. Immunohistochemical staining of native MOR after recording LC neurons was not sufficiently sensitive to determine disruption of internalization by GRK2i (data not shown). However, under the same recording conditions, intracellular application of GRK2i peptide prevented endocytosis of Flag-tagged MOR (Borgland et al., 2003) in cultured AtT20 cells (see Fig. 3). Nine cells in total were filled with GRK2i/biocytin. Of these, GRK2i completely blocked ME-induced internalization of FLAG-MOR in six cells, one cell showed marginal internalization of FLAG-MOR, and the remaining two cells showed moderate but reduced internalization, suggesting that the peptide disrupts MOR internalization as expected. No internalization was observed in untreated, biocytin-filled cells not exposed to ME (see Fig. 3A) $(n=4)$ but was observed in all biocytin-filled cells exposed to ME (see Fig. $3 B)(n=6)$.

As reported previously (Dang et al., 2009), disruption of GRK2 function alone did not affect MOR desensitization in neurons from w.t. or $\beta$ arr-2 k.o. mice (Fig. $2 B$ ). As predicted from results in $\beta$ arr- 2 k.o. mice, disruption of GRK2 function in neurons from w.t. mice significantly increased the rate of MOR resensitization (Fig. 2B) (two-factor ANOVA, $p<0.0001$, all points to $30 \mathrm{~min}$ GRK2i vs w.t. control). Whereas MOR activation of GIRK approaches full recovery after 70 min under control conditions, complete recovery was observed after 20-30 min in neurons filled intracellularly with GRK2i.

In addition to GRK2 and $\beta$ arr-2, LC neurons also express GRK3, GRK5, and GRK6 (Erdtmann-Vourliotis et al., 2001) and Barr-1 (Fan et al., 2003). It is possible that MOR endocytosis can occur via $\beta$ arr-1-dependent mechanism after phosphorylation 


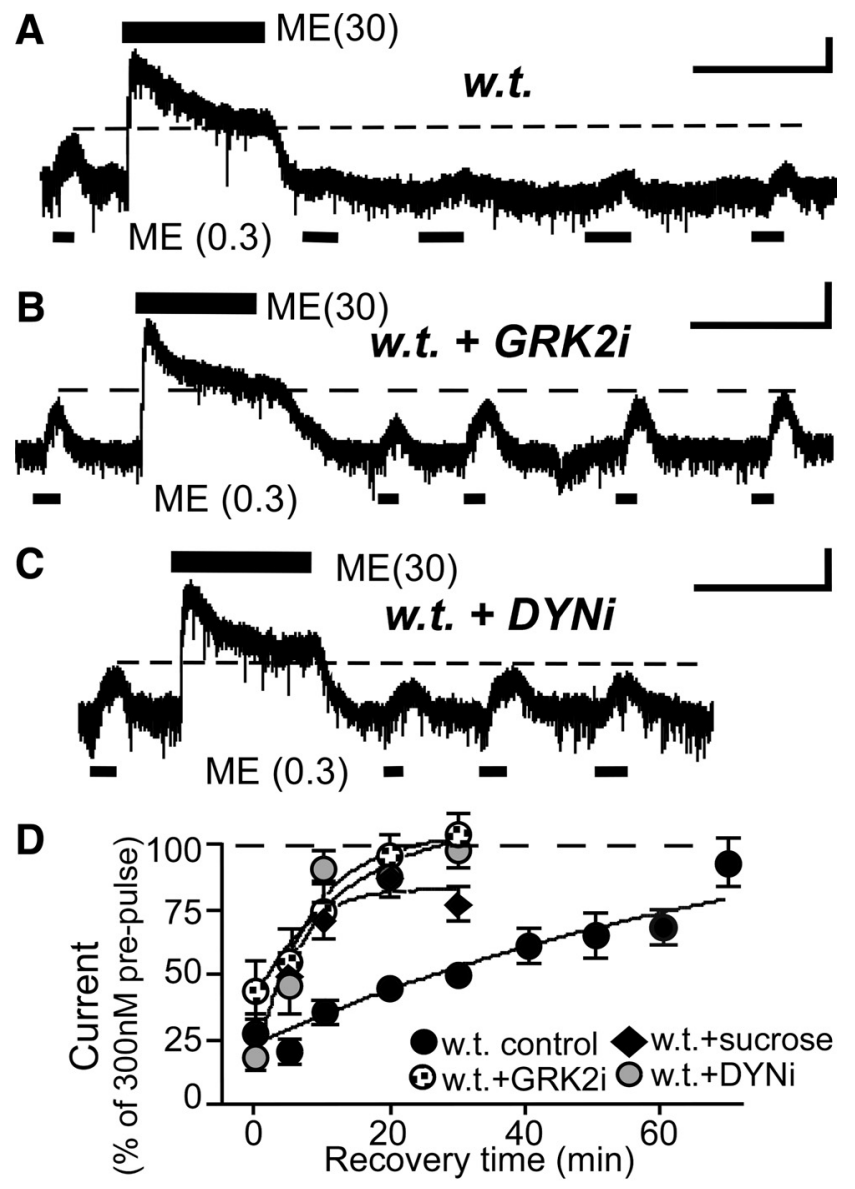

$\mathbf{E}$

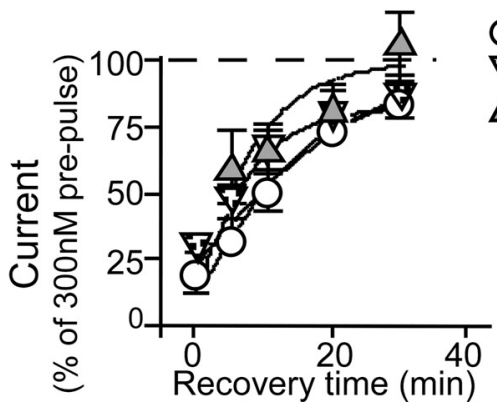

Figure 2. Disruption of $\beta$ arr-2-dependent MOR trafficking facilitates MOR resensitization. $\boldsymbol{A}$, Example of a w.t. neuron showing modest resensitization after 30 min recovery from $10 \mathrm{~min} M E$ desensitization. Recovery was facilitated when $\mathrm{L} C$ neurons from w.t. mice were loaded with GRK2i (B; $100 \mu \mathrm{m} ; n=5-9)$ or DYNi $(\boldsymbol{C} ; 100 \mu \mathrm{m} ; n=5-10)$ via the recording electrode for $\geq 45 \mathrm{~min}$ before the $10 \mathrm{~min}$ ME desensitization treatment. $\boldsymbol{D}$, Summary for neurons with GRK2i, DYNi, or hypertonic sucrose shows that all recover more rapidly from desensitization than control neurons (ME at $30 \mu \mathrm{m}, 10 \mathrm{~min}$ ). E, GRK2i and DYNi did not affect MOR resensitization in LC neurons from $\beta$ arr- 2 k.0. mice (recovery at 30 min for w.t. and $\beta$ arr-2 k.o. Calibration: 25 pA, 10 min.

by other GRKs. To test this, experiments were conducted with DYNi peptide to prevent dynamin-dependent endocytosis, which encompasses all $\beta$ arrestins, and clathrin-dependent endocytosis and perhaps caveolar-mediated endocytosis (Doherty and McMahon, 2009). When DYNi peptide was loaded into w.t. neurons via the recording electrode, MOR resensitization was dramatically accelerated (Fig. 2C,D), with nearly complete recovery after $10 \min (90 \pm 8 \%, n=6)$. The increased rate of recovery with DYNi in w.t. LC neurons was slightly faster than in $\beta$ arr-2 k.o. neurons without DYNi ( $p<0.001$, two-factor ANOVA). Figure
$2 E$ shows that disruption of dynamin function with DYNi peptide also slightly facilitated MOR resensitization in neurons from $\beta$ arr- 2 k.o. mice (two-factor ANOVA, $p<0.01$, but post hoc tests for individual time points did not differ). In contrast, recovery in the presence of DYNi did not differ between w.t. and $\beta$ arr-2 k.o. neurons (two-factor ANOVA, $p>0.66$ ). This suggests that there may be some dynamin-dependent MOR endocytosis in LC neurons from $\beta$ arr- 2 k.o. mice, perhaps mediated by $\beta$ arr-1, that partially contributes to the attenuation of MOR resensitization.

To confirm that DYNi peptide can block dynamin function, DYNi was loaded into cultured AtT20 cells using the same loading conditions as that used for electrophysiological recordings. Confocal imaging of MOR endocytosis in AtT20 cells shows that DYNi peptide robustly blocked dynamindependent endocytosis (Fig. 3). DYNi completely inhibited internalization in six of eight cells filled with DYNi/biocytin. In the remaining two cells, slight internalization could be visualized, suggesting that the peptide disrupts MOR internalization as expected.

To further establish whether MOR endocytosis is required for MOR resensitization, LC neurons from w.t. mice were treated with hypertonic sucrose $(50 \mathrm{~mm})$ before and during ME desensitization. We have reported previously that treatment of slices with hypertonic sucrose $(50 \mathrm{~mm})$ impairs vesicle recycling and presumably endocytosis (Bagley et al., 2005b). Similar to blocking dynamin-dependent endocytosis with DYNi peptide, hypertonic sucrose did not affect MOR activation of GIRK currents or acute desensitization but significantly enhanced the rate of MOR resensitization (Fig. 2E) (two-factor ANOVA, $p<0.0001$ ). Together, these results strongly suggest that MOR resensitized more efficiently when MOR endocytosis was disrupted.

In the absence of MOR endocytosis, MOR resensitization is the same for LC neurons from w.t. and $\beta$ arr- 2 k.o. mice If $\beta$ arr-2-mediated MOR trafficking and endocytosis causes the difference in the rate of recovery in neurons from w.t. and $\beta$ arr-2 k.o. mice, then the rate and magnitude of MOR resensitization should be similar for neurons from w.t. and $\beta$ arr- 2 k.o. mice under conditions for which MOR endocytosis is minimal. To test this hypothesis, MOR resensitization of LC neurons from w.t. and $\beta$ arr- 2 k.o. mice was determined after MOR activation of GIRK was briefly desensitized for $\leq 2 \mathrm{~min}$ using $30 \mu \mathrm{M} \mathrm{ME}$ to achieve a more rapid peak response than could be achieved with $10 \mu \mathrm{M}$ during very brief agonist exposure. Similar results were obtained in several cells exposed to $10 \mu \mathrm{M} \mathrm{ME} \mathrm{(data} \mathrm{not} \mathrm{shown).}$ This treatment has been shown to produce significant MOR desensitization but cause little or no detectable MOR endocytosis (Borgland et al., 2003; Arttamangkul et al., 2006). Indeed, desensitization treatment that causes little or no MOR endocytosis mediates indistinguishable MOR desensitization and resensitization in neurons from w.t. and $\beta$ arr-2 k.o. mice (Fig. 4). Neurons from both w.t. and $\beta$ arr- 2 k.o. mice exhibited nearly complete recovery after $10 \mathrm{~min}(93 \pm 6$ and $81 \pm 6 \%$, respectively). Together, the results show that $\beta$ arr-2-dependent receptor endocytosis attenuates MOR resensitization and is not an obligatory component of the resensitization process as thought previously.

Inhibition of protein phosphatase function prevents MOR resensitization

Dephosphorylation of desensitized GPCRs is considered essential for receptor resensitization (Osborne and Williams, 1995; Zhang et 
al., 1997a; Oakley et al., 1999; Qiu et al., 2003). Inhibition of dephosphorylation by intracellular application of the relatively selective protein phosphatase 1 and 2A inhibitor microcystin (Gehringer, 2004) was reported to slow MOR resensitization in rat LC neurons (Osborne and Williams, 1995), but this could have disrupted either intracellular recycling mechanisms or cell surface resensitization. To test whether receptor dephosphorylation is required for MOR resensitization in LC neurons when arrestin-dependent mechanisms are blocked, microcystin (25 nM) was included in the recording electrode, as described previously (Osborne and Williams, 1995). Figure 5 shows that accelerated MOR resensitization (GRK2i in ßarr-2 k.o. neurons) was significantly suppressed in the presence of microcystin (two-factor ANOVA, $p<$ 0.0001 ). After a partial recovery in the first 5 min after desensitization ( $\mathrm{ME}$ at $30 \mu \mathrm{M}, 10$ $\mathrm{min})$, no additional recovery developed for the remainder of the experiment. These results suggest that dephosphorylation of desensitized MOR is essential for complete recovery of receptor function, and this occurs efficiently, independent of GRK2- $\beta$ arr-2-dependent MOR trafficking.

\section{LC neurons from $\beta$ arr-2 knock-out mice elude cellular tolerance after chronic morphine treatment}

Chronic morphine treatment induces cellular tolerance, defined here as the rightward shift in the concentration-response curve for MOR effector signaling, which is associated with reduced efficacy of both MOR activation of GIRK (Christie et al., 1987) and inhibition of voltage-gated calcium channels in LC (Connor et al., 1999) and various other neurons (Bagley et al., 2005a). However, the mechanisms responsible are still unknown. Previous studies have reported that morphine analgesic tolerance is greatly attenuated in $\beta$ arr- 2 k.o. mice, as is tolerance to MOR-activated GTP $\gamma \mathrm{S}$ binding in brainstem membranes (Bohn et al., 2000, 2002). To determine whether this occurs for MOR-activated GIRK in LC neurons, w.t. and $\beta$ arr- 2 k.o. mice were treated with a sustained release preparation of morphine or vehicle for $6 \mathrm{~d}$ as described previously (Connor et al., 1999). LC slices were prepared and maintained in the absence of morphine for $1 \mathrm{~h}$ before experimental recordings. Figure 6 shows that the concentration-response curve for ME activation of GIRK currents in neurons from morphine-treated w.t. mice is depressed and shifted to the right, representing MOR tolerance in single neurons (two-factor ANOVA, drug treatment effect, $p<0.0001$ ). This is consistent with previous reports for LC neurons from morphine-treated rats (Christie et al., 1987; Dang and Williams, 2004). When the same experiments were conducted in neurons from morphine-treated $\beta$ arr- 2 k.o. mice, the concentration-response curves were superimposed (two-factor ANOVA, $p>0.65$ ), indicating that cellular tolerance was abolished.
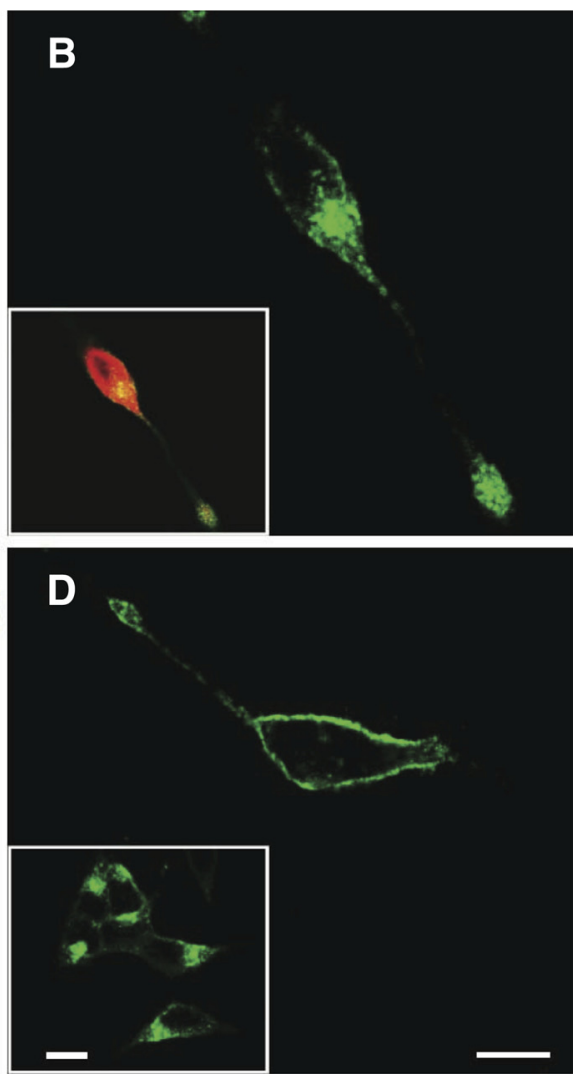

Figure 3. Representative confocal images of individual AtT20 cells expressing FLAG-MOR. Cells were filled for 10 min with biocytin alone or with biocytin plus either GRK2i or DYNi using the whole-cell patch-clamp technique as described in Materials and Methods before inducing internalization with $\mathrm{ME}\left(30 \mu \mathrm{M}, 30 \mathrm{~min}, 37^{\circ} \mathrm{C}\right)$. Electrodes were withdrawn and internalization experiof FLAG-MOR in nonfilled surrounding cells exposed to ME from the same coverslip; biocytin staining present but omitted for clarity. Confocal images represent a $0.7 \mu \mathrm{m}$ optical sections taken from a $z$-stack to include the nucleus. Scale bars, $10 \mu \mathrm{m}$.

\section{Impaired MOR resensitization in LC neurons from chronic morphine-treated mice is rescued by disruption of}

$\beta$ arr-2-dependent MOR regulation and dynamin-dependent endocytosis

Previous studies have shown that, concurrently with cellular morphine tolerance in LC neurons (Christie et al., 1987), chronic morphine treatment modified MOR regulation such that receptor resensitization was impaired, even after a very brief desensitization treatment with ME (Dang and Williams, 2004). Attenuated MOR resensitization could contribute to opioid tolerance by reducing the number of functional receptors at the cell surface. The mechanism of impaired MOR resensitization after morphine treatment is not known. Having shown that $\beta$ arr-2dependent MOR trafficking and dynamin-dependent endocytosis can attenuate MOR resensitization in LC neurons from opioid-naive mice, experiments were conducted to determine whether these processes contribute to impaired MOR resensitization after chronic morphine treatment. To accomplish this, MOR resensitization from brief desensitization treatment (as shown in Fig. 4) was determined in neurons from chronic morphine-treated (6 d) w.t. and $\beta$ arr- 2 k.o. mice. In opioid-naive mice, neurons from both w.t. and $\beta$ arr- 2 k.o. mice exhibited the same extent of desensitization (Dang et al., 2009) and indistin- 

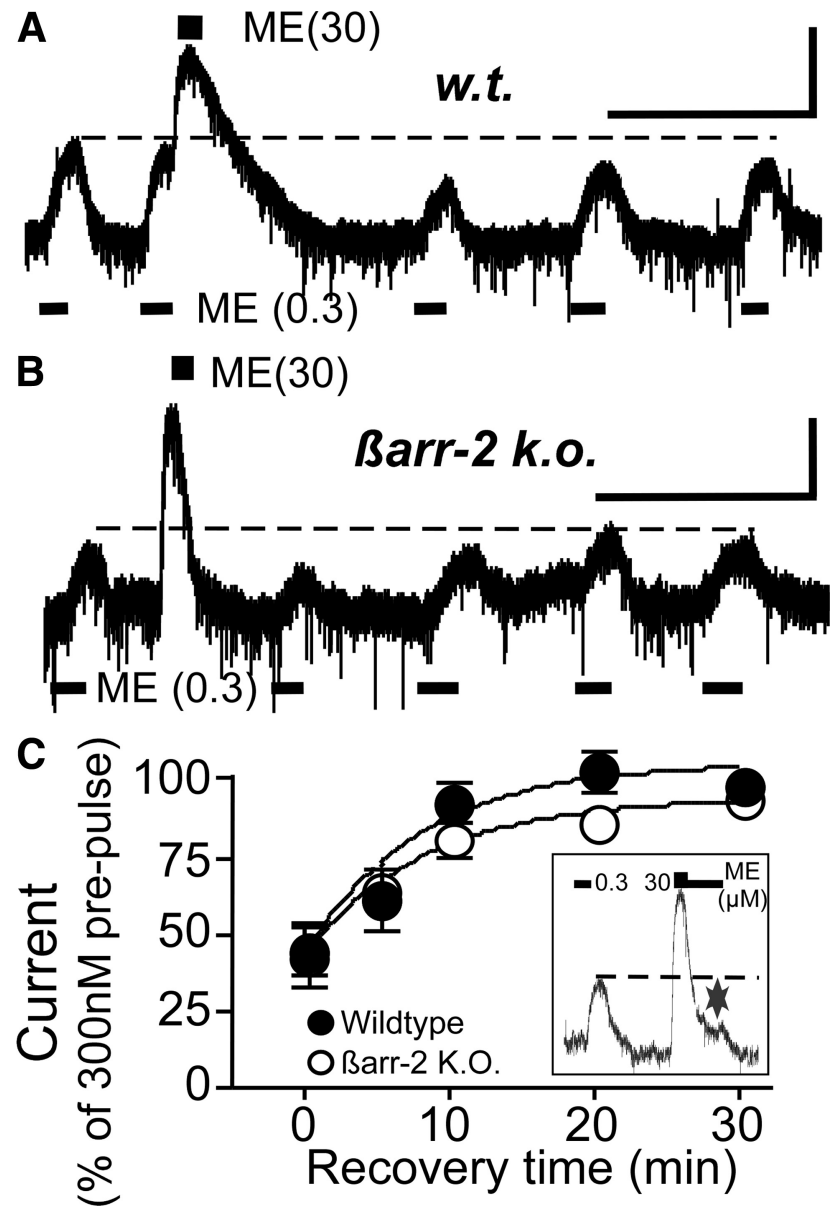

Figure 4. Neurons from w.t. and ßarr-2 k.o. mice have similar rates of recovery from $2 \mathrm{~min}$ desensitization treatment. Current recording from 2 min desensitization treatment $(30 \mu \mathrm{M} \mathrm{ME}$, $2 \mathrm{~min})$ in w.t. $(\boldsymbol{A} ; n=5-8)$ and $\beta$ arr-2 k.o. $(\boldsymbol{B} ; n=5-8)$ mice. $\boldsymbol{C}$, Summary showing the same degree of desensitization and resensitization for neurons from w.t. ( $n=8-9$ neurons) and $\beta$ arr-2 k.o. ( $n=6-8$ neurons) mice. Inset shows example of determination of the initial, 2 min, recovery point. Two-factor ANOVA, $p=0.390$. Calibration: $25 \mathrm{pA}, 10 \mathrm{~min}$.

guishable rates of resensitization (Fig. 4). Consistent with what had been reported for LC neurons from morphine-treated rats (Dang and Williams, 2004), recovery of MOR activation of GIRK from a very brief ( $\leq 2 \mathrm{~min})$ desensitization treatment was greatly attenuated in neurons from morphine-treated w.t. mice compared with w.t. control (vehicle-treated) mice (Fig. 7). However, chronic morphine treatment did not impair MOR resensitization in neurons from $\beta$ arr- 2 k.o mice, suggesting that $\beta$ arr-2-dependent processes cause the impaired MOR resensitization after chronic morphine treatment. To validate this, neurons from chronic morphine-treated w.t. mice were loaded intracellularly with GRK2i or DYNi. Rapid MOR resensitization was rescued in neurons from chronic morphine-treated w.t. mice when either GRK2 or dynamin function was disrupted (Fig. 7). Together, these results show that chronic morphine treatment impairs MOR resensitization in LC neurons in a GRK2- $\beta$ arr-2-dynamin-dependent manner. This finding may provide an explanation for the lack of cellular MOR tolerance in LC neurons from $\beta$ arr-2 k.o. mice.

\section{Discussion}

This study establishes that MOR resensitization from acute desensitization does not require $\beta$ arr- 2 or dynamin-dependent MOR trafficking. To the contrary, $\beta$ arr-2-dependent trafficking
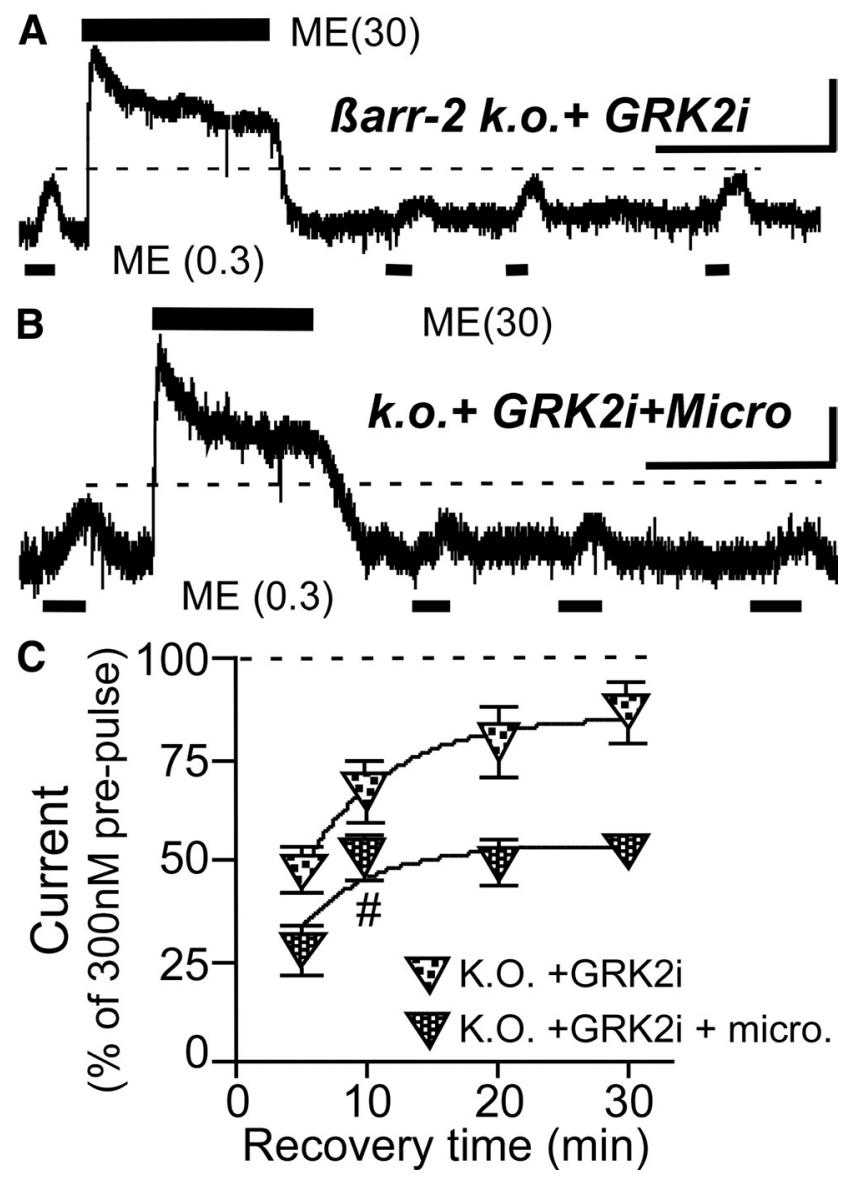

Figure 5. Microcystin prevents full recovery of MOR from acute desensitization. $A$, Recording under conditions that block $\beta$ arr-2-dependent MOR internalization (see Fig. 3). Recovery from 10 min desensitization was complete after 30 min recovery time $(n=5-7)$. $\boldsymbol{B}$, Under the same condition as $\boldsymbol{A}$, microcystin (Micro) prevented MOR recovery from $10 \mathrm{~min}$ ME desensitization $\left(n=5-8\right.$ cells, 8 animals). C, Summary showing that, after an initial recovery at $10 \mathrm{~min}\left({ }^{\#} p<\right.$ 0.05 , paired $t$ test), microcystin treatment prevented additional recovery of MOR from desensitization. Two-factor ANOVA, $p<0.0001$. Calibration: 25 pA, $10 \mathrm{~min}$.

and presumably endocytosis attenuate MOR resensitization under basal conditions. Although it was not possible to quantify whether the manipulations used during patch-clamp recording (GRK2i and DYNi) disrupt endocytosis of native MOR in LC neurons, the same manipulations and recording conditions did block endocytosis of Flag-tagged MOR in cultured cells, suggesting that the inhibitory peptides function as expected and reported (Dang et al., 2009). Interestingly, $\beta$ arr-2-dependent mechanisms are involved in the impairment of MOR resensitization in LC neurons caused by chronic morphine treatment. When $\beta$ arr- 2 is deleted, cellular opioid tolerance in LC neurons is abolished and recovery of MOR function from a brief desensitization treatment resembles that seen in neurons from opioid-naive mice.

\section{MOR resensitization does not require}

Barr-2-dependent endocytosis

This study suggests that, unlike the mechanisms of $\beta 2$ adrenoceptor regulation (Zhang et al., 1997b; Oakley et al., 1999; Gainetdinov et al., 2004), MOR resensitization in LC neurons does not require $\beta$ arr-2-dependent mechanisms. When MOR endocytosis was presumably impaired by deletion of $\beta$ arr- 2 , disruption of GRK2 function, or disruption of dynamin function, MOR resensitization was similarly accelerated rather than inhibited. Furthermore, intracellular application of a phosphatase 

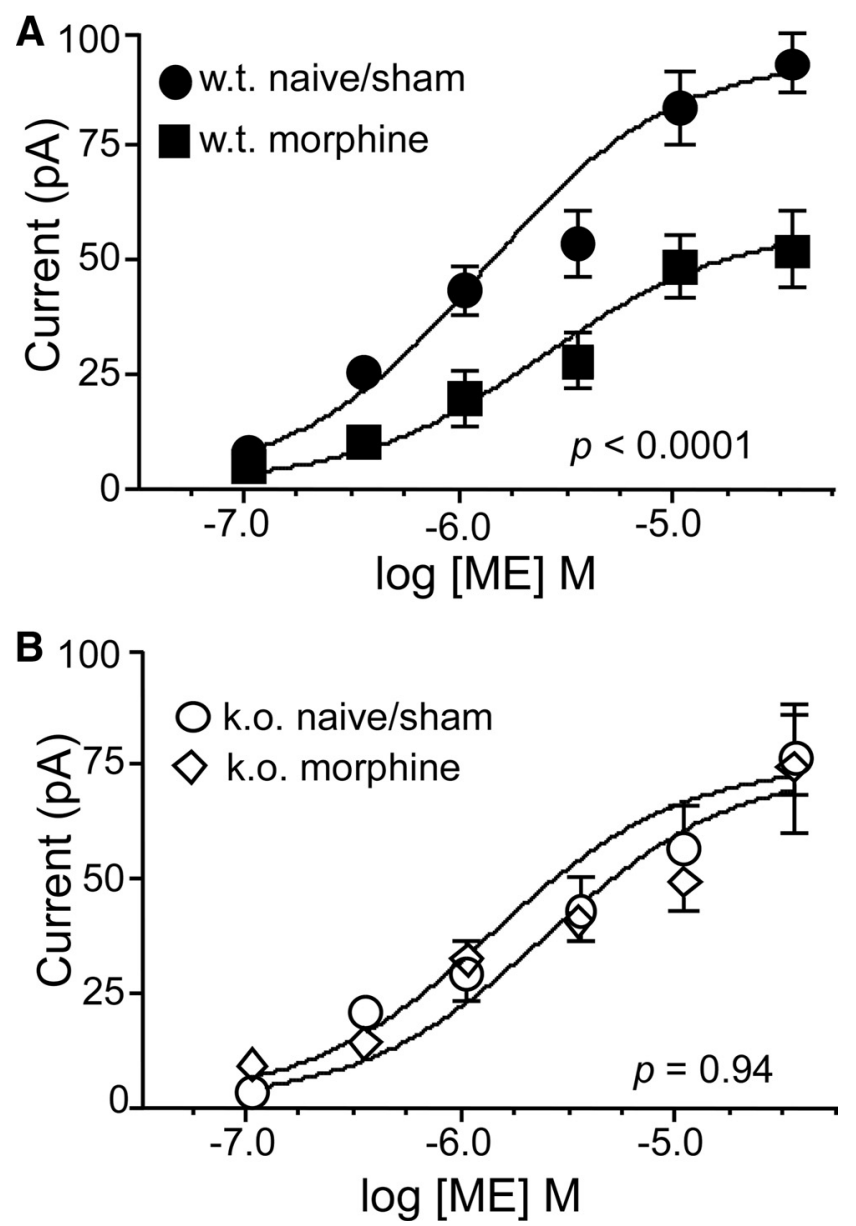

Figure 6. Morphine treatment reduces opioid responsiveness in neurons from w.t. but not in neurons from $\beta$ arr-2 k.o. mice. $A$, Concentration-response curves for neurons from naive/sham ( $n=3-11)$ and chronic morphine-treated $(n=4-14)$ w.t. mice. MOR sensitivity to ME is reduced in neurons from morphine-treated w.t. mice (two-factor ANOVA, $p<0.0001$ ). $\boldsymbol{B}$, Concentration-response curves from naive/sham $(n=4-12)$ and morphine-treated $(n=$ 4-12) $\beta$ arr-2 k.o. mice. Two-factor ANOVA, $p=0.940$.

inhibitor in the absence of $\beta$ arrestin-dependent receptor trafficking (GRK2 inhibition in $\beta$ arr-2 k.o.) prevented full recovery of MOR function, suggesting that MOR dephosphorylation is required for MOR resensitization and that this can occur independently of $\beta$ arr-2-dependent MOR trafficking and endocytosis. The ability of MOR to dephosphorylate and resensitize rapidly when GRK2 and $\beta$ arr-2 processes are disrupted is consistent with the observation that blocking endocytosis with concanavalin A in cultured LC neurons did not prevent MOR resensitization (Arttamangkul et al., 2006). Together with the latter, the present findings challenge the notion that $\beta$ arr-2dependent internalization is required for MOR dephosphorylation and resensitization.

MOR activates GIRK via a membrane delimited interaction with $G \beta \gamma$ subunits released from heterotrimeric G-protein activation, providing a direct and rapid measurement of receptor function in intact cells (Connor et al., 2004). Comparison of changes in GIRK currents evoked by a submaximal concentration of ME (300 nM) applied before and after treatment with supramaximal ME $(30 \mu \mathrm{M})$ provides a sensitive measure of receptor desensitization and resensitization (Connor et al., 2004). In this and other studies in LC and DRG neurons (Walwyn et al., 2007; Dang et al., 2009), the basal efficacy of coupling between
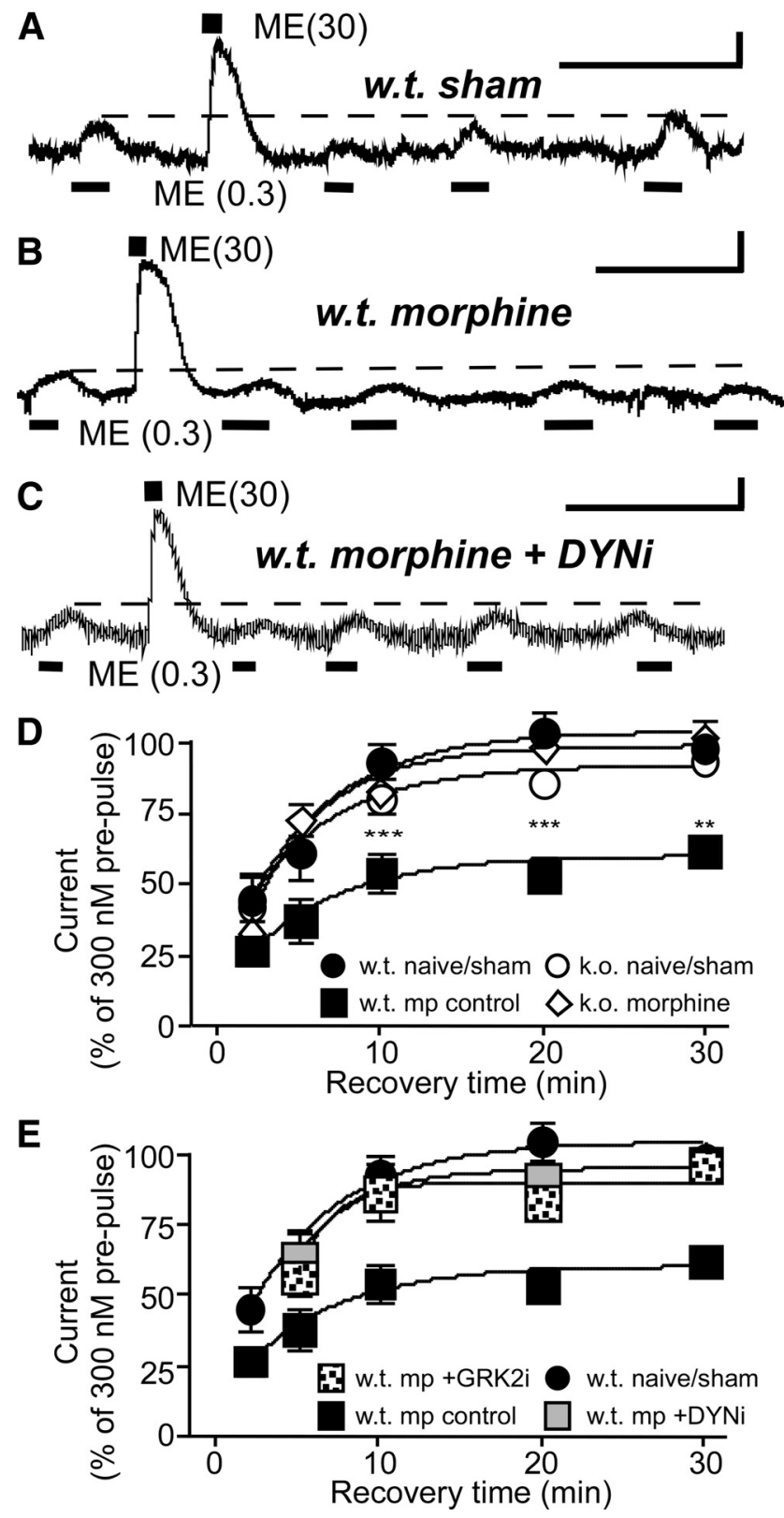

Figure 7. Blocking $\beta$ arr-2-dependent MOR trafficking rescues MOR resensitization in neurons from morphine-treated mice. Recordings of MOR resensitization from 2 min desensitization in neurons from naive/vehicle $(\boldsymbol{A} ; n=5-8)$ and chronic morphine-treated $(\boldsymbol{B} ; n=8-10)$ w.t. mice. After chronic morphine treatment, MOR resensitization is incomplete. $C$, Blocking dynamin function, with DYNi peptide, rescued MOR resensitization from 2 min desensitization in neurons from chronic morphine-treated w.t. mice $(n=6-7)$. D , Summary of MOR resensitization from 2 min desensitization treatment shows that chronic morphine (mp) impaired resensitization in neurons from w.t mice but not neurons $\beta$ arr- 2 k.0. mice (two-factor ANOVA, $p<0.0001$ w.t. morphine vs naïve; post hoc tests, $\left.{ }^{* *} p<0.01,{ }^{* * *} p<0.001\right)$.E, Summary of MOR resensitization in neurons from naive/sham $(n=5-8)$ and morphine-treated (mp; $n=$ 3-8) w.t. mice showing that attenuated resensitization is rescued by GRK2i and DYNi w.t. (control from D shown for comparison). Calibration: $25 \mathrm{pA}, 10 \mathrm{~min}$.

MOR and G $\beta \gamma$ subunit modulated ion channels was slightly reduced in $\beta$ arr- 2 k.o. mice. This contrasts with original studies of GTP $\gamma \mathrm{S}$ binding assays in membranes from several regions (Bohn et al., 1999, 2000, 2002) that found enhanced efficacy of MOR GTP $\gamma \mathrm{S}$ binding in $\beta$ arr- 2 k.o. mice. The basis for the difference is unknown. It could involve different neuronal populations as suggested by behavioral studies (Raehal et al., 2005), signaling in an 
intact, native neuronal environment versus membranes, or perhaps different forms of regulation that might develop during protracted GTP $\gamma \mathrm{S}$ assays [2 $\mathrm{h}$ (Connor et al., 2004)].

When MOR resensitization was assessed in neurons from opioid-naive w.t. mice, the rate of resensitization was similar to that reported previously for LC neurons from rat (Osborne and Williams, 1995) and similar to the rate of MOR recycling reported in cultured cells (Tanowitz and von Zastrow, 2003). This suggests that the slow resensitization observed in neurons from naive w.t. mice reflects the rate of recycling of endocytosed MOR back to the plasma membrane. However, when Barr-2dependent MOR endocytosis is disrupted, MOR resensitization was greatly facilitated. Thus, under conditions in which endocytosis is impaired by inhibition of GRK2, deletion of $\beta$ arr-2, or inhibition of dynamin, the increased rate of MOR resensitization presumably reflects the absence of intracellular trafficking of endocytosed receptors as determined for the $\beta 2$ adrenoceptor (Oakley et al., 2000).

Some studies have implied that MOR recycling is a necessary step for MOR resensitization (Koch et al., 1998, 2001; Law et al., 2000; Qiu et al., 2003). Treatment of cells with monensin to inhibit endosomal recycling (Law et al., 2000; Qiu et al., 2003), truncated MOR mutants (Qiu et al., 2003), or MOR splice variants (Koch et al., 1998, 2001; Tanowitz et al., 2008) all reduced the recycling and resensitization of endocytosed MOR in parallel. Although the present findings show that MOR resensitization occurs efficiently when arrestin/dynamin-dependent mechanisms are blocked, the results remain compatible with the fact that, once receptors are endocytosed, relatively slow receptor recycling (Tanowitz et al., 2008) is necessary for recovery of MOR localization and signaling at the surface membrane.

Biochemical studies implicating a necessity for MOR recycling in resensitization (Koch et al., 1998, 2001; Law et al., 2000) were generally performed over timescales greatly exceeding acute desensitization of G-protein $\beta \gamma$ subunit mobilization as measured by GIRK activation (see above), $\beta$ arr-2 binding (Oakley et al., 2000), and endocytosis (Tanowitz and von Zastrow, 2003; Arttamangkul et al., 2006; Yu et al., 2009). Therefore, such methods cannot readily distinguish recovery of functional MOR at the cell surface from increased MOR surface density (and therefore function) resulting from recycling (Connor et al.,2004). In contrast, the findings that monensin also reduces the rate of MOR resensitization in LC neurons (Dang and Williams, 2004), together with concanavalin A, which blocks MOR endocytosis but not resensitization (Arttamangkul et al., 2006), are consistent with the current finding that $\beta$ arr-2, dynamin-dependent mechanisms slow MOR resensitization.

The process of MOR endocytosis involves sequential GRK phosphorylation of agonist bound receptor, binding of arrestins (particularly $\beta$ arr-2), and dynamin-dependent receptor endocytosis (Kovoor et al., 1998; Gainetdinov et al., 2004). Given that LC neurons express $\beta$ arr-1 (Fan et al., 2003), it is possible that neurons from $\beta$ arr-2 k.o. mice can mediate MOR endocytosis via a ßarr-1-dependent mechanism (Oakley et al., 2000). When DYNi was loaded into LC neurons from $\beta$ arr- 2 k.o. mice, MOR resensitization was further enhanced, suggesting that desensitization may have caused some MOR endocytosis in $\beta$ arr-2 k.o. mice, possibly mediated by $\beta$ arr- 1 . It is also possible that caveolarmediated MOR endocytosis facilitates MOR resensitization in the absence of $\beta$ arr-2-dependent process. This is unlikely because dynamin inhibition, which accelerated MOR resensitization, blocks clathrin-dependent and perhaps caveolar-mediated endocytosis (Doherty and McMahon, 2009).

\section{Barr-2 trafficking is required for opioid tolerance in LC neurons}

The finding that morphine treatment failed to produce cellular tolerance in LC neurons from $\beta$ arr- 2 k.o. mice is consistent with the findings that tolerance to DAMGO-stimulated GTP $\gamma S$ binding in brainstem and spinal cord membranes is attenuated in these animals (Bohn et al., 2000, 2002). This was attributed to ablation of $\beta$ arr-2-dependent desensitization of MOR (Bohn et al., 1999, 2000), which was not found here in LC (Dang et al., 2009) or DRG (Walwyn et al., 2007) neurons, but the term "desensitization" did not refer to the same MOR regulatory process because rapid desensitization during sustained presence of agonist was not determined in the GTP $\gamma \mathrm{S}$ assays (Bohn et al., 1999, 2000, 2002).

The results suggest that persistence of rapid recovery from desensitization after chronic morphine could contribute to the attenuation of behavioral opioid tolerance in $\beta$ arr- 2 k.o. mice if the mechanism found in LC generalizes to analgesia-related neurons. We propose that, after chronic morphine, $\beta$ arr-2dependent regulation of MOR is enhanced, slowing MOR resensitization, thereby shifting the equilibrium between receptor desensitization and resensitization to an accumulation of desensitized MOR that accounts for MOR tolerance. Therefore, ablation of $\beta$ arr-2 in the k.o. mice facilitates resensitization and prevents cellular opioid tolerance in LC neurons. The precise mechanism of $\beta$ arr-2-dependent impairment of resensitization during chronic morphine treatment in vivo is not known, but the present study shows that impaired MOR resensitization after a brief ME desensitization treatment can be rescued in LC neurons from morphine-treated w.t. mice, either by disrupting GRK2 function or inhibition of dynamin function. In light of recent reports effectively showing that morphine mediates $\beta$ arr- 2 recruitment to the MOR, albeit less efficiently than agonists such as DAMGO (McPherson et al., 2010), as well as inducing MOR endocytosis in neurons (Yu et al., 2009), these findings link the impairment of MOR resensitization and cellular opioid tolerance in LC to adaptations within the process of GRK2- $\beta$ arr-2dynamin-dependent MOR regulation rather than accumulation of inactive MOR at the cell surface as was suggested from studies in cultured HEK293 cells (Koch et al., 2005).

In conclusion, this study has established that $\beta$ arrestindynamin-dependent endocytosis is not necessary for MOR resensitization as thought previously. Resensitization proceeds efficiently when $\beta$ arrestin-dependent endocytosis is disrupted. $\beta$ arr-2-dependent receptor endocytosis actually slows the rate of MOR resensitization, which is presumably attributable to the slow rate of recycling of endocytosed receptors. After chronic morphine treatment, $\beta$ arr-2-dependent receptor regulation can contribute to cellular tolerance by impairing MOR resensitization. Although opioid actions in LC are not clearly linked to antinociception, if the mechanisms identified here can be generalized to neurons in pain pathways, it may lead to more rational therapies to limit analgesic tolerance in vivo.

\section{References}

Arttamangkul S, Torrecilla M, Kobayashi K, Okano H, Williams JT (2006) Separation of ì-opioid receptor desensitization and internalization: endogenous receptors in primary neuronal cultures. J Neurosci 26:4118-4125.

Bagley EE, Chieng BC, Christie MJ, Connor M (2005a) Opioid tolerance in periaqueductal gray neurons isolated from mice chronically treated with morphine. Br J Pharmacol 146:68-76.

Bagley EE, Gerke MB, Vaughan CW, Hack SP, Christie MJ (2005b) GABA 
transporter currents activated by protein kinase A excite midbrain neurons during opioid withdrawal. Neuron 45:433-445.

Bailey CP, Kelly E, Henderson G (2004) Protein kinase C activation enhances morphine-induced rapid desensitization of mu-opioid receptors in mature rat locus ceruleus neurons. Mol Pharmacol 66:1592-1598.

Bohn LM, Lefkowitz RJ, Gainetdinov RR, Peppel K, Caron MG, Lin FT (1999) Enhanced morphine analgesia in mice lacking beta-arrestin 2. Science 286:2495-2498.

Bohn LM, Gainetdinov RR, Lin FT, Lefkowitz RJ, Caron MG (2000) Muopioid receptor desensitization by beta-arrestin-2 determines morphine tolerance but not dependence. Nature 408:720-723.

Bohn LM, Lefkowitz RJ, Caron MG (2002) Differential mechanisms of morphine antinociceptive tolerance revealed in $\beta$ arrestin-2 knock-out mice. J Neurosci 22:10494-10500.

Borgland SL, Connor M, Osborne PB, Furness JB, Christie MJ (2003) Opioid agonists have different efficacy profiles for $\mathrm{G}$ protein activation, rapid desensitization, and endocytosis of mu-opioid receptors. J Biol Chem 278:18776-18784.

Buntin-Mushock C, Phillip L, Moriyama K, Palmer PP (2005) Agedependent opioid escalation in chronic pain patients. Anesth Analg 100:1740-1745.

Christie MJ, Williams JT, North RA (1987) Cellular mechanisms of opioid tolerance: studies in single brain neurons. Mol Pharmacol 32:633-638.

Connor M, Borgland SL, Christie MJ (1999) Continued morphine modulation of calcium channel currents in acutely isolated locus coeruleus neurons from morphine-dependent rats. Br J Pharmacol 128:1561-1569.

Connor M, Osborne PB, Christie MJ (2004) Mu-opioid receptor desensitization: is morphine different? Br J Pharmacol 143:685-696.

Dang VC, Williams JT (2004) Chronic morphine treatment reduces recovery from opioid desensitization. J Neurosci 24:7699-7706.

Dang VC, Williams JT (2005) Morphine-induced mu-opioid receptor desensitization. Mol Pharmacol 68:1127-1132.

Dang VC, Napier IA, Christie MJ (2009) Two distinct mechanisms mediate acute ì-opioid receptor desensitization in native neurons. J Neurosci 29:3322-3327.

Doherty GJ, McMahon HT (2009) Mechanisms of endocytosis. Annu Rev Biochem 78:857-902.

Erdtmann-Vourliotis M, Mayer P, Ammon S, Riechert U, Höllt V (2001) Distribution of G-protein-coupled receptor kinase (GRK) isoforms 2, 3, 5 and 6 mRNA in the rat brain. Brain Res Mol Brain Res 95:129-137.

Fan XL, Zhang JS, Zhang XQ, Yue W, Ma L (2003) Differential regulation of beta-arrestin 1 and beta-arrestin 2 gene expression in rat brain by morphine. Neuroscience 117:383-389.

Gainetdinov RR, Premont RT, Bohn LM, Lefkowitz RJ, Caron MG (2004) Desensitization of $\mathrm{G}$ protein-coupled receptors and neuronal functions. Annu Rev Neurosci 27:107-144.

Gehringer MM (2004) Microcystin-LR and okadaic acid-induced cellular effects: a dualistic response. FEBS Lett 557:1-8.

Keith DE, Murray SR, Zaki PA, Chu PC, Lissin DV, Kang L, Evans CJ, von Zastrow M (1996) Morphine activates opioid receptors without causing their rapid internalization. J Biol Chem 271:19021-19024.

Kieffer BL, Gaveriaux-Ruff C (2002) Exploring the opioid system by gene knockout. Prog Neurobiol 66:285-306.

Koch T, Schulz S, Schröder H, Wolf R, Raulf E, Höllt V (1998) Carboxylterminal splicing of the rat mu opioid receptor modulates agonistmediated internalization and receptor resensitization. J Biol Chem 273:13652-13657.

Koch T, Schulz S, Pfeiffer M, Klutzny M, Schröder H, Kahl E, Höllt V (2001) $\mathrm{C}$-terminal splice variants of the mouse mu-opioid receptor differ in morphine-induced internalization and receptor resensitization. J Biol Chem 276:31408-31414.

Koch T, Widera A, Bartzsch K, Schulz S, Brandenburg LO, Wundrack N, Beyer A, Grecksch G, Höllt V (2005) Receptor endocytosis counteracts the development of opioid tolerance. Mol Pharmacol 67:280-287.

Koch WJ, Inglese J, Stone WC, Lefkowitz RJ (1993) The binding site for the beta gamma subunits of heterotrimeric $\mathrm{G}$ proteins on the beta-adrenergic receptor kinase. J Biol Chem 268:8256-8260.

Kovoor A, Celver JP, Wu A, Chavkin C (1998) Agonist induced homologous desensitization of mu-opioid receptors mediated by $\mathrm{G}$ proteincoupled receptor kinases is dependent on agonist efficacy. Mol Pharmacol 54:704-711.

Law PY, Erickson LJ, El-Kouhen R, Dicker L, Solberg J, Wang W, Miller E, Burd AL, Loh HH (2000) Receptor density and recycling affect the rate of agonist-induced desensitization of mu-opioid receptor. Mol Pharmacol 58:388-398.

Li AH, Wang HL (2001) G protein-coupled receptor kinase 2 mediates muopioid receptor desensitization in GABAergic neurons of the nucleus raphe magnus. J Neurochem 77:435-444.

McPherson J, Rivero G, Baptist M, Llorente J, Al-Sabah S, Krasel C, Dewey WL, Bailey CP, Rosethorne EM, Charlton SJ, Henderson G, Kelly E (2010) $\mu$-Opioid receptors: correlation of agonist efficacy for signalling with ability to activate internalization. Mol Pharmacol 78:756-766.

Oakley RH, Laporte SA, Holt JA, Barak LS, Caron MG (1999) Association of beta-arrestin with $G$ protein-coupled receptors during clathrin-mediated endocytosis dictates the profile of receptor resensitization. J Biol Chem 274:32248-32257.

Oakley RH, Laporte SA, Holt JA, Caron MG, Barak LS (2000) Differential affinities of visual arrestin, beta arrestin1, and beta arrestin2 for G protein-coupled receptors delineate two major classes of receptors. J Biol Chem 275:17201-17210.

Osborne PB, Williams JT (1995) Characterization of acute homologous desensitization of mu-opioid receptor-induced currents in locus coeruleus neurones. Br J Pharmacol 115:925-932.

Qiu Y, Law PY, Loh HH (2003) Mu-opioid receptor desensitization: role of receptor phosphorylation, internalization, and representation. J Biol Chem 278:36733-36739.

Raehal KM, Walker JK, Bohn LM (2005) Morphine side effects in betaarrestin 2 knockout mice. J Pharmacol Exp Ther 314:1195-1201.

Scavone JL, Van Bockstaele EJ (2009) Mu-opioid receptor redistribution in the locus coeruleus upon precipitation of withdrawal in opiate-dependent rats. Anat Rec (Hoboken) 292:401-411.

Sternini C, Spann M, Anton B, Keith DE Jr, Bunnett NW, von Zastrow M, Evans C, Brecha NC (1996) Agonist-selective endocytosis of mu opioid receptor by neurons in vivo. Proc Natl Acad Sci U S A 93:9241-9246.

Tanowitz M, von Zastrow M (2003) A novel endocytic recycling signal that distinguishes the membrane trafficking of naturally occurring opioid receptors. J Biol Chem 278:45978-45986.

Tanowitz M, Hislop JN, von Zastrow M (2008) Alternative splicing determines the post-endocytic sorting fate of G-protein-coupled receptors. J Biol Chem 283:35614-35621.

von Zastrow M (2001) Role of endocytosis in signalling and regulation of G-protein-coupled receptors. Biochem Soc Trans 29:500-504.

von Zastrow M, Svingos A, Haberstock-Debic H, Evans C (2003) Regulated endocytosis of opioid receptors: cellular mechanisms and proposed roles in physiological adaptation to opiate drugs. Curr Opin Neurobiol 13:348-353.

Walwyn W, Evans CJ, Hales TG (2007) â-Arrestin2 and c-Src regulate the constitutive activity and recycling of ì-opioid receptors in dorsal root ganglion neurons. J Neurosci 27:5092-5104.

Yu YJ, Arttamangkul S, Evans CJ, Williams JT, von Zastrow M (2009) Neurokinin 1 receptors regulate morphine-induced endocytosis and desensitization of ì-opioid receptors in CNS neurons. J Neurosci 29:222-233.

Zhang J, Barak LS, Winkler KE, Caron MG, Ferguson SS (1997a) A central role for beta-arrestins and clathrin-coated vesicle-mediated endocytosis in beta2-adrenergic receptor resensitization. Differential regulation of receptor resensitization in two distinct cell types. J Biol Chem 272:27005-27014.

Zhang J, Ferguson SS, Barak LS, Aber MJ, Giros B, Lefkowitz RJ, Caron MG (1997b) Molecular mechanisms of $G$ protein-coupled receptor signaling: role of $\mathrm{G}$ protein-coupled receptor kinases and arrestins in receptor desensitization and resensitization. Receptors Channels 5:193-199. 